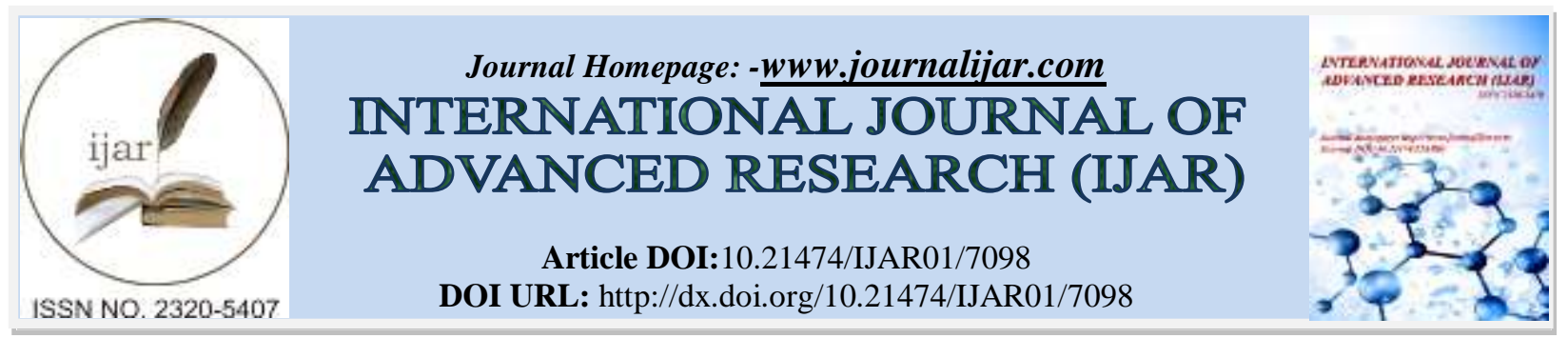

RESEARCH ARTICLE

\title{
AN INVESTIGATION ON THE STRUCTURAL, SPECTRAL AND MAGNETIC PROPERTIES OF NB- ZN DOPED BARIUM STRONTIUM HEXAFERRITE NANOCOMPOSITE POWDER SYNTHESIZED BY SOL-GEL METHOD.
}

\author{
S. Gayathri ${ }^{1}$, $S$. Jesurani ${ }^{1}$, K. Ashok ${ }^{2}$ and A. John Peter ${ }^{3}$. \\ 1. PG and Research Department of Physics, Jayaraj Annapackiam College for Women Periyakulam- 625601, \\ Tamilnadu, India. \\ 2. Materials and Mechanical Entity, Vikram Sarabhai Space Centre (ISRO), Thiruvananthapuram-695022, Kerala, \\ India. \\ 3. P.G and Research Dept.of Physics, Government Arts College, Melur-625 106. Madurai. India.
}

\section{Manuscript Info}

Manuscript History

Received: 14 March 2018

Final Accepted: 16 April 2018

Published: May 2018

Keywords:-

Barium Strontium hexaferrite, Sol-gel,

Structural properties, Spectral properties,

Magnetic properties.

\section{Abstract}

$\mathrm{Nb}-\mathrm{Zn}$ doped Barium Strontium hexaferrite $\mathrm{Ba}_{0.5} \mathrm{Sr}_{0.5} \mathrm{Fe}_{12}$ ${ }_{2 \mathrm{x}} \mathrm{Nb}_{\mathrm{x}} \mathrm{Zn}_{\mathrm{x}} \mathrm{O}_{19}(\mathrm{X}=0,0.05,0.1,0.25,0.5 \mathrm{~mol} \%)$ nanocomposite powder were synthesized by sol-gel process using D-glucose as a fuel. The prepared samples were calcined at $950^{\circ} \mathrm{C}$. TGA/DTA curve shows there is no weight loss above $850^{\circ} \mathrm{C}$ which confirmed the formation of barium strontium hexaferrite. FTIR spectra exhibit the band in the range of $453-495 \mathrm{~cm}^{-1}$ which revealed the presence of hexagonal ferrite. X-ray diffraction (XRD) confirmed the formation of hexagonal structure with some additional peaks of $\mathrm{Fe}_{2} \mathrm{O}_{3}$. The average particle size of the sample is in the range of $39-47 \mathrm{~nm}$. SEM micrographs showed the powder is well crystallized and the particles are hexagonal structure with needle shape and platelet form. EDAX analysis showed the evidence for the presence of $\mathrm{Ba}, \mathrm{Sr}, \mathrm{Fe}, \mathrm{Nb}$ and $\mathrm{Zn}$. The VSM measurement revealed that the doping of $\mathrm{Nb}-\mathrm{Zn}$ ions caused the change in the magnetic properties such as coercivity, saturation magnetization and remanence magnetization. The improving saturation magnetization and remanence magnetization and reducing coercivity were favorable for high density perpendicular magnetic recording applications.

Copy Right, IJAR, 2018,. All rights reserved.

\section{Introduction:-}

The hexagonal ferrites, $\mathrm{MFe}_{12} \mathrm{O}_{19}(\mathrm{M}=\mathrm{Ba}, \mathrm{Sr}, \mathrm{Pb})$, with the magnetoplumbite structure type continue to be important permanent magnet materials in microwave, small motor, and, more recently, perpendicular and longitudinal high-density magnetic recording media[1]. These types of ferrites have large saturation magnetization, high coercivity, high Curie temperature, large uniaxial magnetic anisotropy and excellent chemical stability.

The microwave magnetic materials works either near the natural resonance, as electromagnetic interference shielding materials or absorbers. Off-resonance, they work as high permeable, low-loss materials in devices like isolators, inductor cores circulators, phase shifters, filters, etc. In comparison with garnet and spinel ferrites, the magnetoplumbite structure is hexagonal in symmetry. Most of the popular microwave hexaferrites are derived from 
the M-type hexaferrite. M-type hexagonal ferrites are known for their strong uniaxial magneto-crystalline anisotropy with easy magnetization along c-axis [2]. In the M-type hexaferrite, the twelve $\mathrm{Fe}^{3+}$ ions occupy five crystallographic sites, such as the $2 \mathrm{a}$ (one $\mathrm{Fe}^{3+}$ ion), $12 \mathrm{k}$ (six $\mathrm{Fe}^{3+}$ ions) and $2 \mathrm{~b}$ (one $\mathrm{Fe}^{3+}$ ion) with up-spin configuration, and the $4 \mathrm{f}_{1}$ (two $\mathrm{Fe}^{3+}$ ions) and $4 \mathrm{f}_{2}$ (two $\mathrm{Fe}^{3+}$ ions) with down-spin configuration [3]. Partial substitutions of $\mathrm{Sr}^{2+}$ or $\mathrm{Ba}^{2+}$ ions and $\mathrm{Fe}^{3+}$ ions by several ions, such as $\mathrm{Mn}^{2+}-\mathrm{cu}^{2+}-\mathrm{Zr}^{4+}, \mathrm{Mn}^{2+}-\mathrm{Co}^{2+}-\mathrm{Ti}^{4+}, \mathrm{Bi}^{3+}-\mathrm{Co}^{2+}-\mathrm{Ti}^{4+}, \mathrm{Zn}$ - $\mathrm{Ti}$ have been reported[4]. $\mathrm{Nb}-\mathrm{Zn}$ substituted Barium Strontium hexaferrite is a new kind of very promising particulate material for magnetic recording [5]. In the present work, Nb-Zn doped M- type hexaferrite $\mathrm{Ba}_{0.5} \mathrm{Sr}_{0.5} \mathrm{Fe}_{12-2 \mathrm{x}} \mathrm{Nb}_{\mathrm{x}} \mathrm{Zn}_{\mathrm{x}} \mathrm{O}_{19}$ (X= 0 to 0.5 mol $\%)$ are prepared by the sol-gel method. The structural, spectral and magnetic properties of Nb-Zn doped M-type Barium Strontium hexaferrite are investigated.

\section{Materials and Synthesis:-}

The $\mathrm{Ba}_{0.5} \mathrm{Sr}_{0.5} \mathrm{Fe}_{12-2 \mathrm{x}} \mathrm{Nb}_{\mathrm{x}} \mathrm{Zn}_{\mathrm{x}} \mathrm{O}_{19}$ nanocomposite powder was prepared by sol-gel method using D-glucose as fuel. Analytical reagent grade $\mathrm{Ba}\left(\mathrm{No}_{2}\right)_{3}, \mathrm{Sr}\left(\mathrm{No}_{2}\right)_{3}, \mathrm{Fe}\left(\mathrm{NO}_{3}\right) .9 \mathrm{H}_{2} \mathrm{O}, \mathrm{Zn}\left(\mathrm{NO}_{2}\right)_{3}, \mathrm{NbCl}_{5}$ and $\mathrm{D}$ - glucose were used as staring materials. According to the composition of $\mathrm{Ba}_{0.5} \mathrm{Sr}_{0.5} \mathrm{Fe}_{12-2 \mathrm{x}} \mathrm{Nb}_{\mathrm{x}} \mathrm{Zn}_{\mathrm{x}} \mathrm{O}_{19}(\mathrm{X}=0,0.05,0.1,0.25,0.5 \mathrm{~mol} \%)$ all the nitrates were separately dissolved in a minimum amount of distilled water and stirred on a magnetic stirrer for 15 minutes. All the solutions were mixed together and stirred on a magnetic stirrer until the nitrates were completely dissolved. The metal nitrates and D-glucose in the molar ratio of 1:1 were dissolved in distilled water to obtain an aqueous solution using magnetic stirrer and then added $4 \mathrm{ml}$ of ethylene glycol which acts as reducing agent and finally gelling agent is added. The resultant solution was stirred continuously and heated up to $80^{\circ} \mathrm{C}$ to obtain a sticky liquid gel. The gel was heated in a hot air oven at $110^{\circ} \mathrm{C}$ for 24 hours to get precursor powder which was used to take FTIR \& TGA/DTA. The resulting nanocomposite powder was calcined at two different temperatures $800^{\circ} \mathrm{C}$ and $950^{\circ} \mathrm{C}$ for 3 hours to obtain $\mathrm{Ba}_{0.5} \mathrm{Sr}_{0.5} \mathrm{Fe}_{12-2 \mathrm{x}} \mathrm{Nb}_{\mathrm{x}} \mathrm{Zn}_{\mathrm{x}} \mathrm{O}_{19}$ powder which is used for XRD, SEM, EDAX and VSM characterizations.

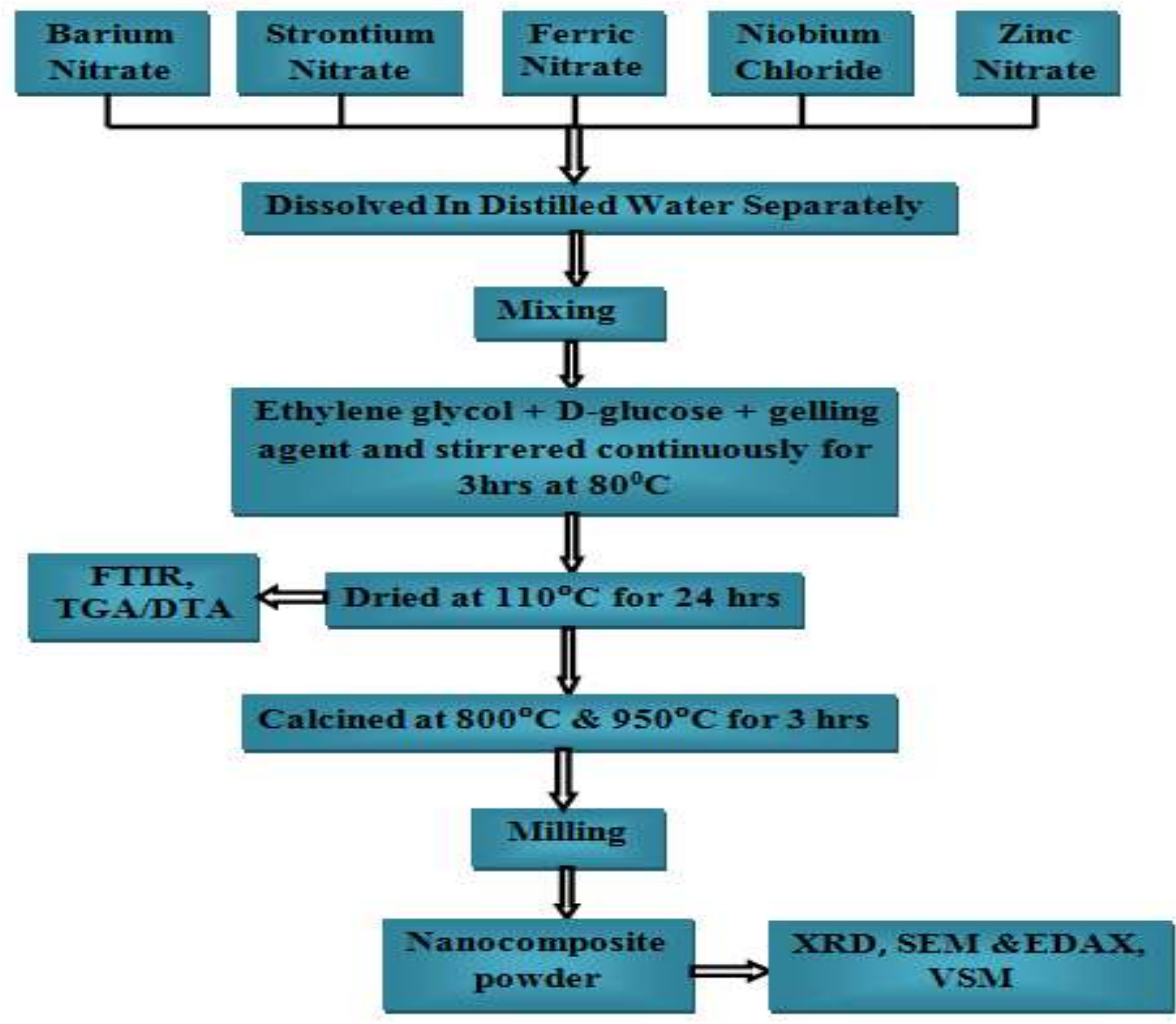

Fig. 1:-Flowchart of synthesis of Nb- Zn doped Barium Strontium hexaferrite

\section{Results and discussion:-}

\section{Thermal analysis:-}

The sample was monitored by thermogravimetric analysis (TGA) and differential thermal analysis (DTA). Fig.2 reflects the TGA/DTA curves of the undoped sample of $\mathrm{Ba}_{0.5} \mathrm{Sr}_{0.5} \mathrm{Fe}_{12} \mathrm{O}_{19}$ with the heating rate at $10^{0} \mathrm{C} / \mathrm{min}$ in air. 
The thermal analysis shows the formation of hexaferrite phase. The first weight loss was observed at about $25^{\circ} \mathrm{C}$ $150^{\circ} \mathrm{C}$ which represents the loss of residual water from the powdered surface. The next weight loss was obtained in the range of $400^{\circ} \mathrm{C}-800^{\circ} \mathrm{C}$ due to the decomposition of the hydroxides of barium, strontium, iron into corresponding metal oxides. In the DTA curve, two distinct exothermic peaks between $200^{\circ} \mathrm{C}$ and $400^{\circ} \mathrm{C}$ are due to the decomposition of D-glucose and one endothermic peak around $576^{\circ} \mathrm{C}$ may be the decomposition of the residual amorphous carbon. From the results, it is clear that the dry glucose burns drastically after absorbing some energy and then gives out great quantity of heat. The exothermic, endothermic and weight loss at temperature between $200^{\circ} \mathrm{C}$ to $800^{\circ} \mathrm{C}$ can be assigned to the starting formation of monoferrite and hexaferrite and there is no noticeable weight loss above $850^{\circ} \mathrm{C}$ which confirmed the formation of barium strontium hexaferrite. The crystalline temperature attained above $850^{\circ} \mathrm{C}$ due to the addition of fuel (D-glucose) [6].

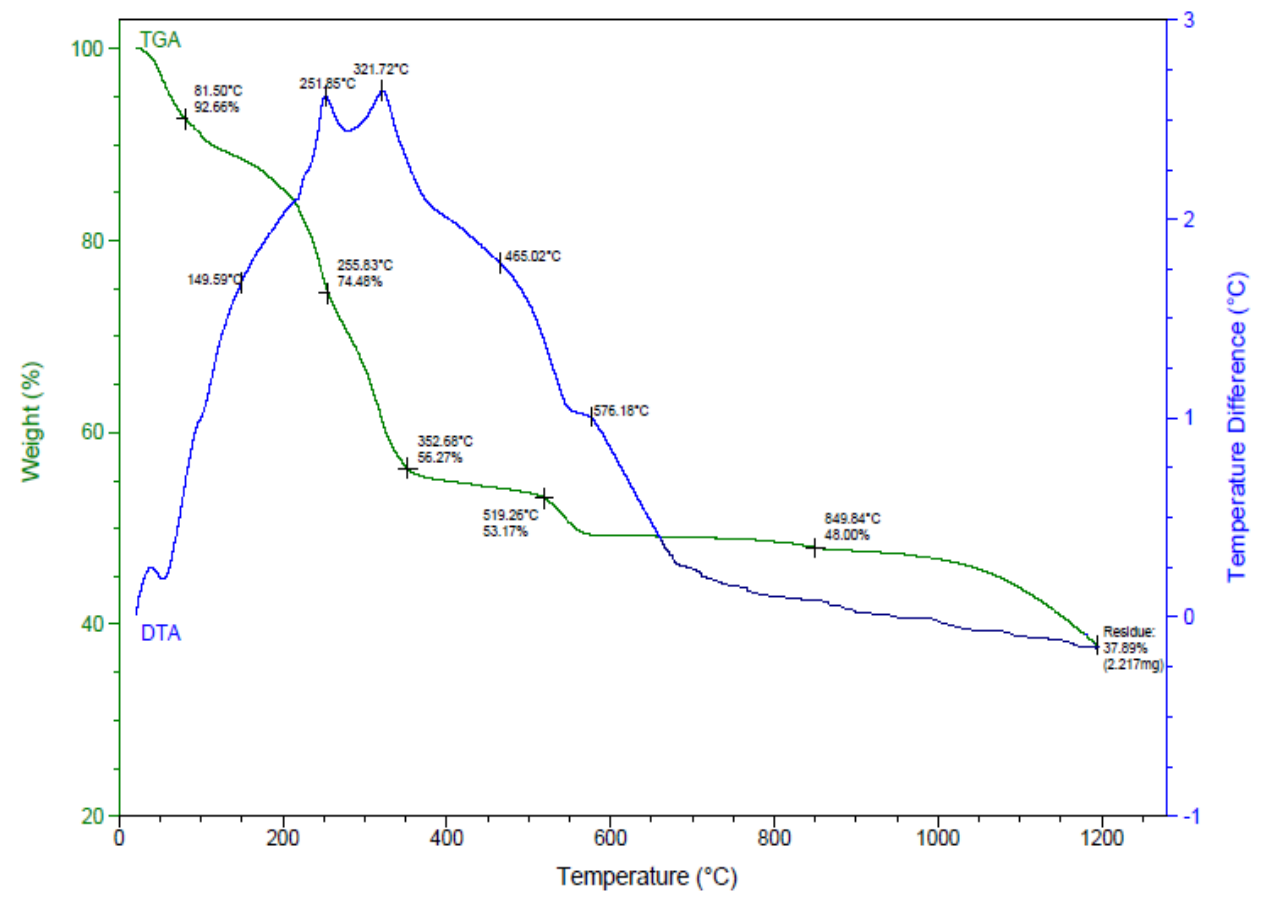

Fig. 2:-TG/DTA curve for $\mathrm{Ba}_{0.5} \mathrm{Sr}_{0.5} \mathrm{Fe}_{12} \mathrm{O}_{19}$

\section{FTIR spectra study:-}

The FTIR spectra of the prepared sample of precursors are shown in fig.3. FTIR Spectra are in the range of 4000$400 \mathrm{~cm}^{-1}$ for the sample with different concentrations. The largest absorption band around 3451 to $3498 \mathrm{~cm}^{-1}$ is attributed to the stretching of water molecules in the band of $\mathrm{O}=\mathrm{H}$. The strongest absorption band is observed between the wave number 1704 and $1724 \mathrm{~cm}^{-1}$ corresponding stretching of vibration $\mathrm{C}=\mathrm{O}$. Another band was located at the wave number $1353-1381 \mathrm{~cm}^{-1}$ in the bending of nitro groups. The small absorption bands are assigned to $\mathrm{C}-\mathrm{O}$ stretching of $1010-1065 \mathrm{~cm}^{-1}$. The sharp absorption peak $797 \mathrm{~cm}^{-1}$ belongs to metal oxide stretching of vibration. The bands around 453 to $495 \mathrm{~cm}^{-1}$ are characteristic peaks which confirmed the presence of hexaferrite. The FTIR spectra showed different functional groups of barium strontium hexaferrite with doping of $\mathrm{Nb}-\mathrm{Zn}$ nanocomposition [7]. 


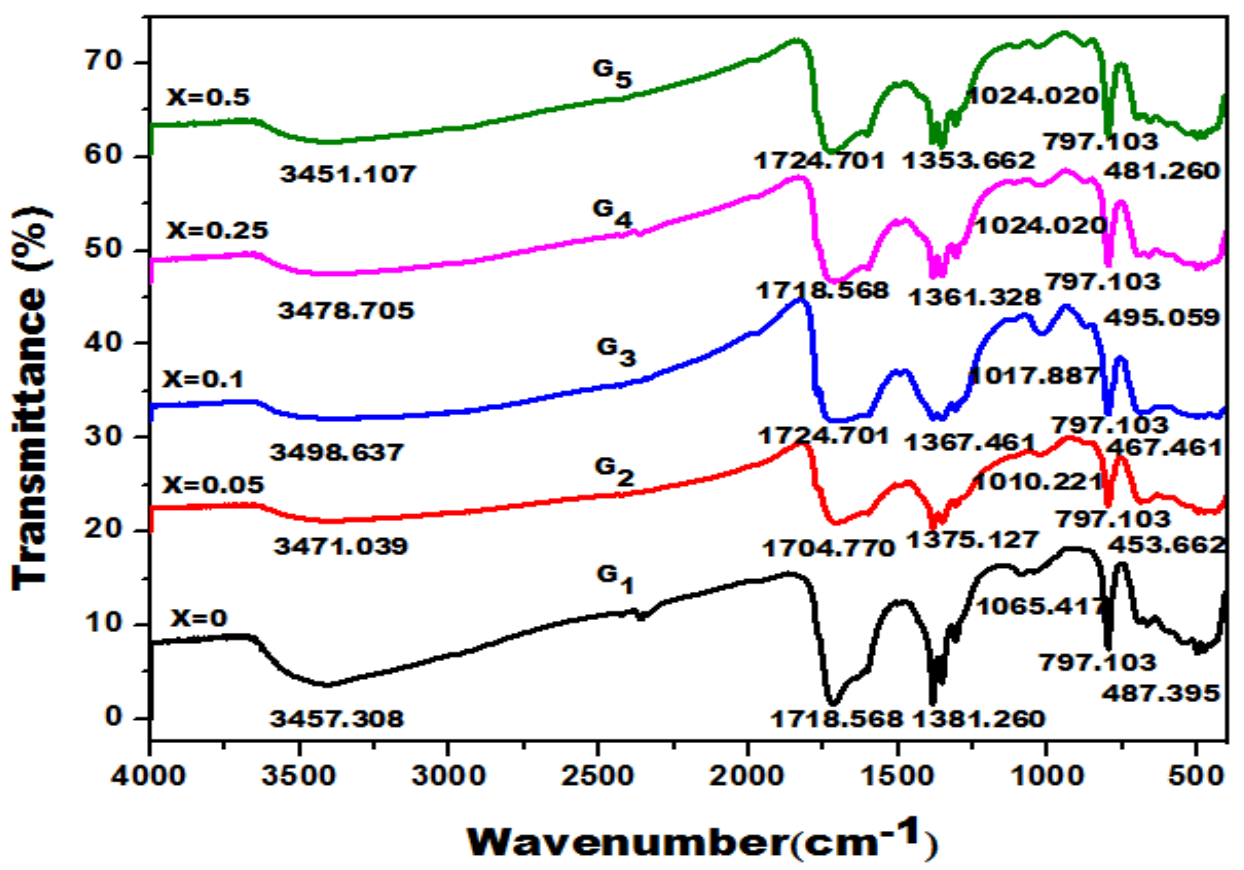

Fig. 3:-FTIR spectra of $\mathrm{Ba}_{0.5} \mathrm{Sr}_{0.5} \mathrm{Fe}_{12-2 \mathrm{x}} \mathrm{Nb}_{\mathrm{x}} \mathrm{Zn}_{\mathrm{x}} \mathrm{O}_{19}$ precursors with (X=0, 0.05, 0.1, 0.25, $\left.0.5 \mathrm{~mol} \%\right)$

Table 1:-FTIR spectra of $\mathrm{Ba}_{0.5} \mathrm{Sr}_{0.5} \mathrm{Fe}_{12-2 \mathrm{x}} \mathrm{Nb}_{\mathrm{x}} \mathrm{Zn}_{\mathrm{x}} \mathrm{O}_{19}$ precursors with (X=0, 0.05, 0.1, 0.25, $\left.0.5 \mathrm{~mol} \%\right)$

\begin{tabular}{|c|c|c|}
\hline Sample & $\begin{array}{c}\text { weight } \\
\text { percentage }\left(\mathrm{cm}^{-1}\right)\end{array}$ & vibrational $\operatorname{mode}\left(\mathrm{cm}^{-1}\right)$ \\
\hline$\left(\mathrm{G}_{1}\right) \mathrm{Ba}_{0.5} \mathrm{Sr}_{0.5} \mathrm{Fe}_{12} \mathrm{O}_{19}$ & 3451-3498 & O-H Stretch \\
\hline$\left(\mathrm{G}_{2}\right) \mathrm{Ba}_{0.5} \mathrm{Sr}_{0.5} \mathrm{Fe}_{11.9} \mathrm{Nb}_{0.05} \mathrm{Zn}_{0.05} \mathrm{O}_{19}$ & 1704-1724 & C = O Stretch \\
\hline$\left(G_{3}\right) B a_{0.5} S_{0.5} F e_{11.8} N b_{0.1} Z_{0.1} \mathbf{O}_{19}$ & 1353-1381 & $\mathrm{N}=\mathrm{O}$ Bend \\
\hline$\left(\mathrm{G}_{4}\right) \mathrm{Ba}_{0.5} \mathrm{Sr}_{0.5} \mathrm{Fe}_{11.5} \mathrm{Nb}_{0.25} \mathrm{Zn}_{0.25} \mathrm{O}_{19}$ & 1010-1065, 797 & C-O Stretch, Metal oxide \\
\hline$\left(G_{5}\right) B_{0.5} S_{0.5} F e_{11} N b_{0.5} Z_{0.5} \mathrm{O}_{19}$ & $453-495$ & Ferrite \\
\hline
\end{tabular}

Structural analysis:-

Fig.4 shows the X-ray diffraction patterns of the $\mathrm{Ba}_{0.5} \mathrm{Sr}_{0.5} \mathrm{Fe}_{12-2 \mathrm{x}} \mathrm{Nb}_{\mathrm{x}} \mathrm{Zn}_{\mathrm{x}} \mathrm{O}_{19}(\mathrm{X}=0,0.05,0.1,0.25,0.5 \mathrm{~mol} \%)$ samples prepared by sol-gel process and then the prepared samples was calcined at $950^{\circ} \mathrm{C}$.X-ray diffraction analysis revealed that all diffraction peaks seen in the XRD pattern well matches with standard pattern of barium strontium hexaferrite (JCPDF\#51-1879). The XRD pattern revealed the formation of the hexagonal magnetoplumbite structure and a small amount of secondary phase $\left(\alpha-\mathrm{Fe}_{2} \mathrm{O}_{3}\right)$ was also present. The extra peak of $\alpha-\mathrm{Fe}_{2} \mathrm{O}_{3}$ has been observed for $\mathrm{X}=0.5$.

The lattice constants a and $\mathrm{c}$ were calculated using the following formula [1]

$$
\frac{1}{d_{h k l}^{2}}=\frac{4}{3}\left(\frac{h^{2}+h k+k^{2}}{a^{2}}\right)+\frac{l^{2}}{c^{2}}
$$

Where $\mathrm{d}$ is the inter-planer spacing and values of ' $\mathrm{h} \mathrm{k} \mathrm{l'}$ ' are miller indices. The values of lattice parameter calculated using above equation (1) are presented in Table 2. Variation of lattice parameters (a, c) as a function of $\mathrm{Nb}-$ $\mathrm{Zn}(\mathrm{X}=0$ to $0.5 \mathrm{~mol} \%)$ content is shown in fig 5 . It is evident that the value of 'a' remains constant, while that of ' $\mathrm{c}$ ' slightly increases with increasing the doping contents. The increase in lattice parameter $\mathrm{c}$ might have been caused by the difference between the ionic radii of $\mathrm{Zn}^{2+}\left(0.74 \mathrm{~A}^{0}\right)$ and $\mathrm{Nb}^{4+}\left(0.69 \mathrm{~A}^{0}\right)$ compared with that of $\mathrm{Fe}^{3+}\left(0.645 \mathrm{~A}^{0}\right)$. The change in lattice parameters vary with the distance between magnetic ions which lead to a change in super exchange interactions and thus to a change in magnetic properties of the samples. This behavior was in good agreement with that of the previous work [8]. 


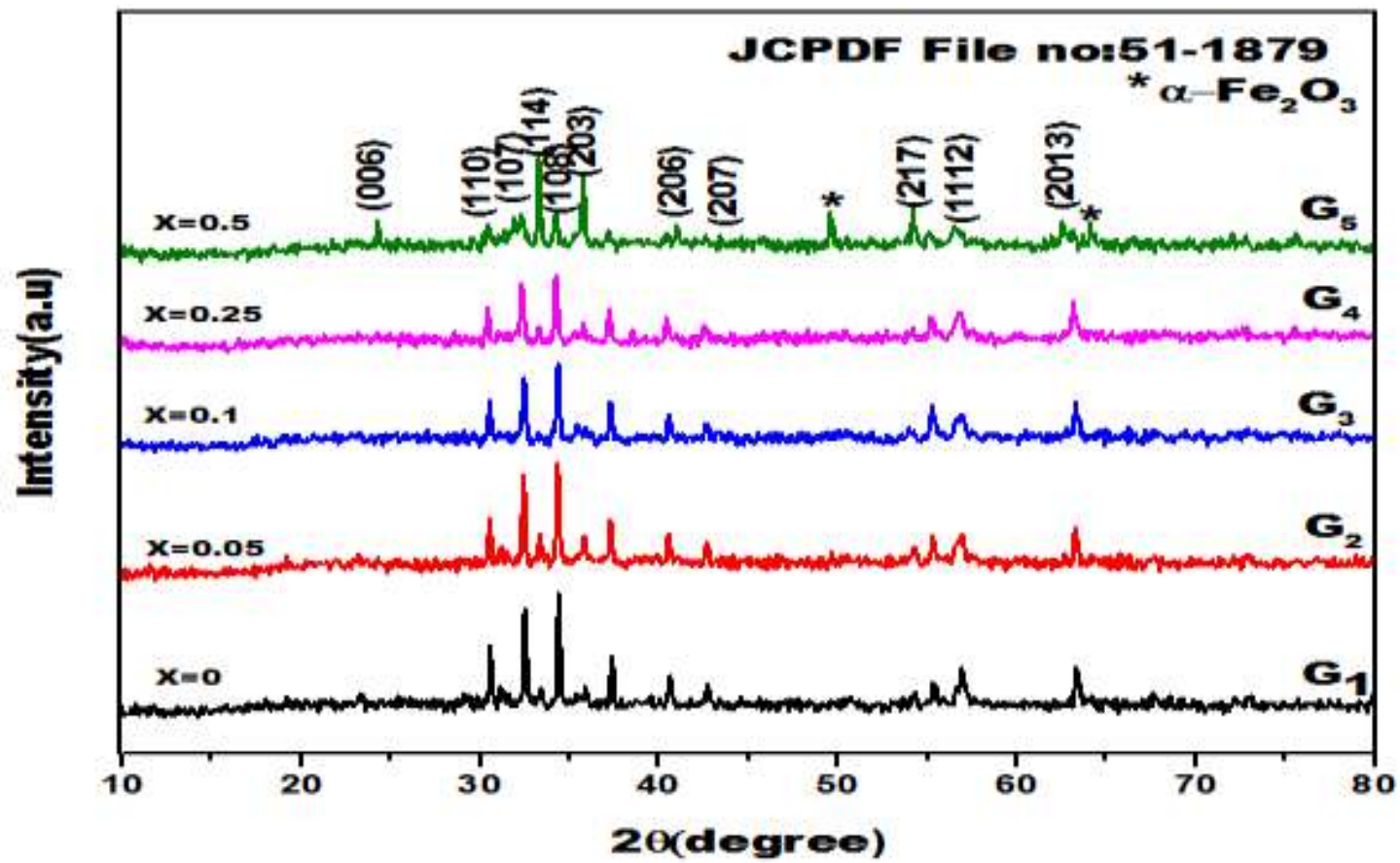

Fig. 4:-XRD pattern of the $\mathrm{Ba}_{0.5} \mathrm{Sr}_{0.5} \mathrm{Fe}_{12-2 \mathrm{x}} \mathrm{Nb}_{\mathrm{x}} \mathrm{Zn}_{\mathrm{x}} \mathrm{O}_{19}(\mathrm{X}=0,0.05,0.1,0.25,0.5 \mathrm{~mol} \%)$ of samples calcined at $\left.950^{\circ} \mathrm{C}\right)$

The particle size of the sample was calculated from Scherrer's formula (2)

$$
\mathbf{D}=\mathbf{k} \lambda / \beta \cos \theta
$$

Where $\mathrm{D}$ is the average crystallite size, $\lambda$ is the $\mathrm{X}$-ray wavelength $\left(1.54060 \mathrm{~A}^{0}\right), \beta$ is the half peak width, $\theta$ is the Bragg's angle and $\mathrm{k}$ - shape factor $(\mathrm{k}=0.89$ for hexagonal system). The average crystallite size determined from $\mathrm{XRD}$ data is in the range of $39-47 \mathrm{~nm}$, indicating the nanocomposition nature of the present samples.

Table2:-Variation of lattice constants (a, c) with changes in the contents of $\mathrm{Nb}-\mathrm{Zn}(\mathrm{X}=0-0.5 \mathrm{~mol} \%)$

\begin{tabular}{|c|c|c|}
\hline Hexaferrite & $\begin{array}{l}\text { Lattice parameters } \\
\mathbf{a}=\mathbf{b}\left(\mathbf{A}^{0}\right)\end{array}$ & Lattice parameter $\mathbf{c}\left(\mathbf{A}^{0}\right)$ \\
\hline $\mathrm{Ba}_{0.5} \mathrm{Sr}_{0.5} \mathrm{Fe}_{12} \mathrm{O}_{19}$ & 5.88 & 23.2 \\
\hline $\mathrm{Ba}_{0.5} \mathrm{Sr}_{0.5} \mathrm{Fe}_{11.9} \mathrm{Nb}_{0.05} \mathrm{Zn}_{0.05} \mathrm{O}_{19}$ & 5.88 & 23.22 \\
\hline $\mathrm{Ba}_{0.5} \mathrm{Sr}_{0.5} \mathrm{Fe}_{11.8} \mathrm{Nb}_{0.1} \mathrm{Zn}_{0.1} \mathrm{O}_{19}$ & 5.88 & 23.26 \\
\hline $\mathrm{Ba}_{0.5} \mathrm{Sr}_{0.5} \mathrm{Fe}_{11.5} \mathrm{Nb}_{0.25} \mathrm{Zn}_{0.25} \mathrm{O}_{19}$ & 5.88 & 23.3 \\
\hline $\mathrm{Ba}_{0.5} \mathrm{Sr}_{0.5} \mathrm{Fe}_{11} \mathrm{Nb}_{0.5} \mathrm{Zn}_{0.5} \mathrm{O}_{19}$ & 5.88 & 23.33 \\
\hline
\end{tabular}




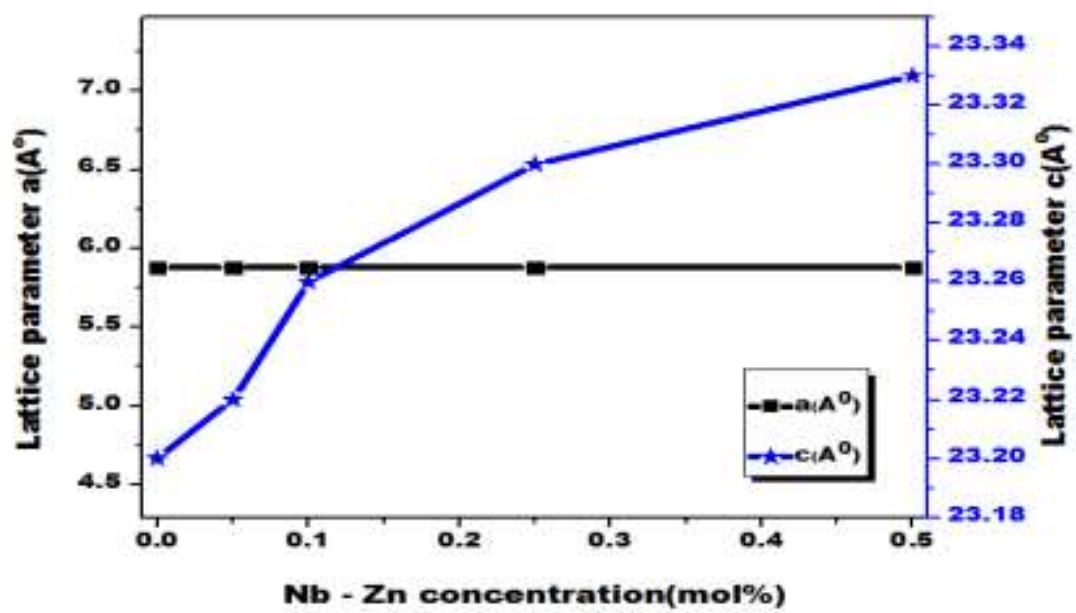

Fig. 5:-Variation of lattice constants (a, c) with changes in the contents of $\mathrm{Nb}-\mathrm{Zn}(\mathrm{x}=0-0.5 \mathrm{~mol} \%)$

\section{Surface morphology analysis:-}

SEM images of Nb-Zn doped Barium Strontium hexaferrite samples ( $\mathrm{x}=0,0.05,0.1,0.25,0.5 \mathrm{~mol} \%)$ are shown in Fig. 6. The shape of the sample $G_{1}$ is the dumble shape, for the sample of $G_{2} \& G_{3}$ are in platelet hexagonal structure, whereas hexagonal with needle shape structure are found in the sample of $\mathrm{G}_{4}$. The sample $\mathrm{G}_{5}$ exhibited the shape of hexagonal along with tiny spherical particles which confirmed the presence of nanocomposite materials. The results of XRD and SEM are matched with each other. The platelet shaped hexaferrite can be used for microwave absorbing purpose [9].
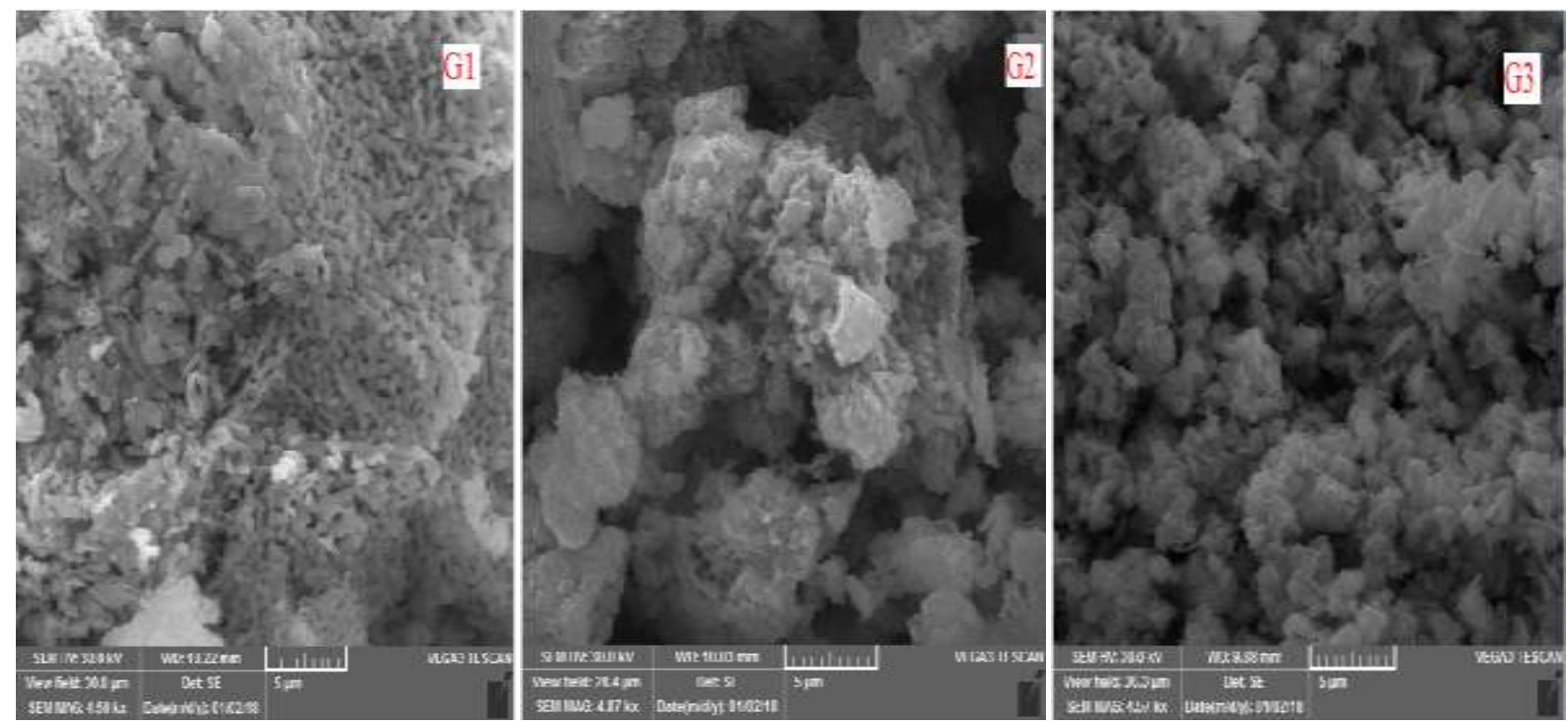

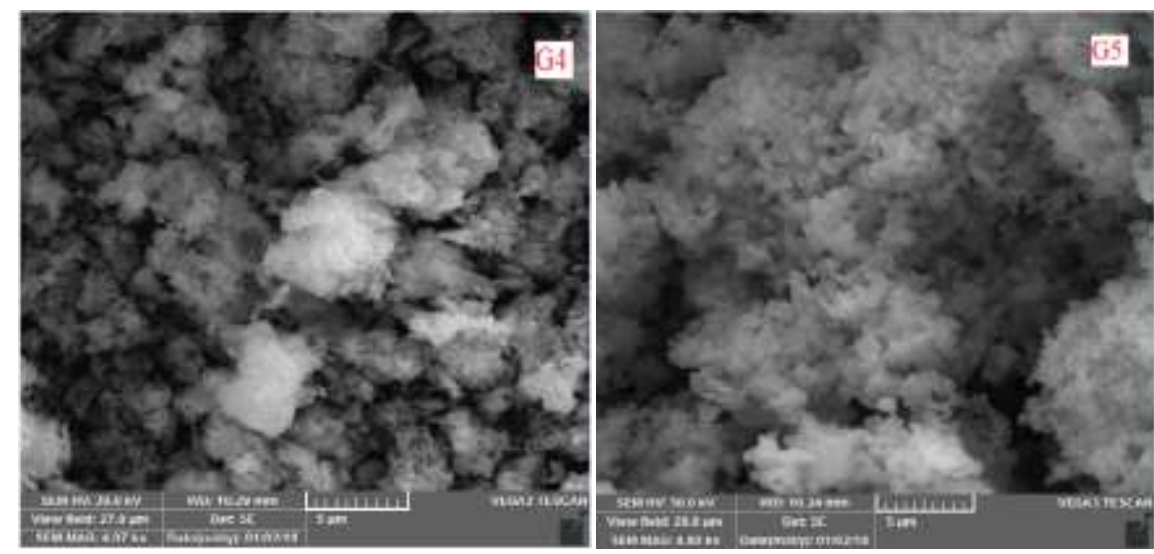

Fig.6:-SEM images of $\mathrm{Ba}_{0.5} \mathrm{Sr}_{0.5} \mathrm{Fe}_{12-2 \mathrm{x}} \mathrm{Nb}_{\mathrm{x}} \mathrm{Zn}_{\mathrm{x}} \mathrm{O}_{19}(\mathrm{X}=0,0.05,0.1,0.25,0.5 \mathrm{~mol} \%)$ with samples Calcined at $\mathbf{9 5 0}^{0} \mathrm{C}$

\section{Energy dispersive $X$-ray spectroscopy:-}

EDAX analysis of $\mathrm{Ba}_{0.5} \mathrm{Sr}_{0.5} \mathrm{Fe}_{12-2 \mathrm{x}} \mathrm{Nb}_{\mathrm{x}} \mathrm{Zn}_{\mathrm{x}} \mathrm{O}_{19}(\mathrm{X}=0,0.05,0.1,0.25,0.5 \mathrm{~mol} \%)$ of samples show the evidence for the presence of barium, strontium, iron, Niobium and Zinc.
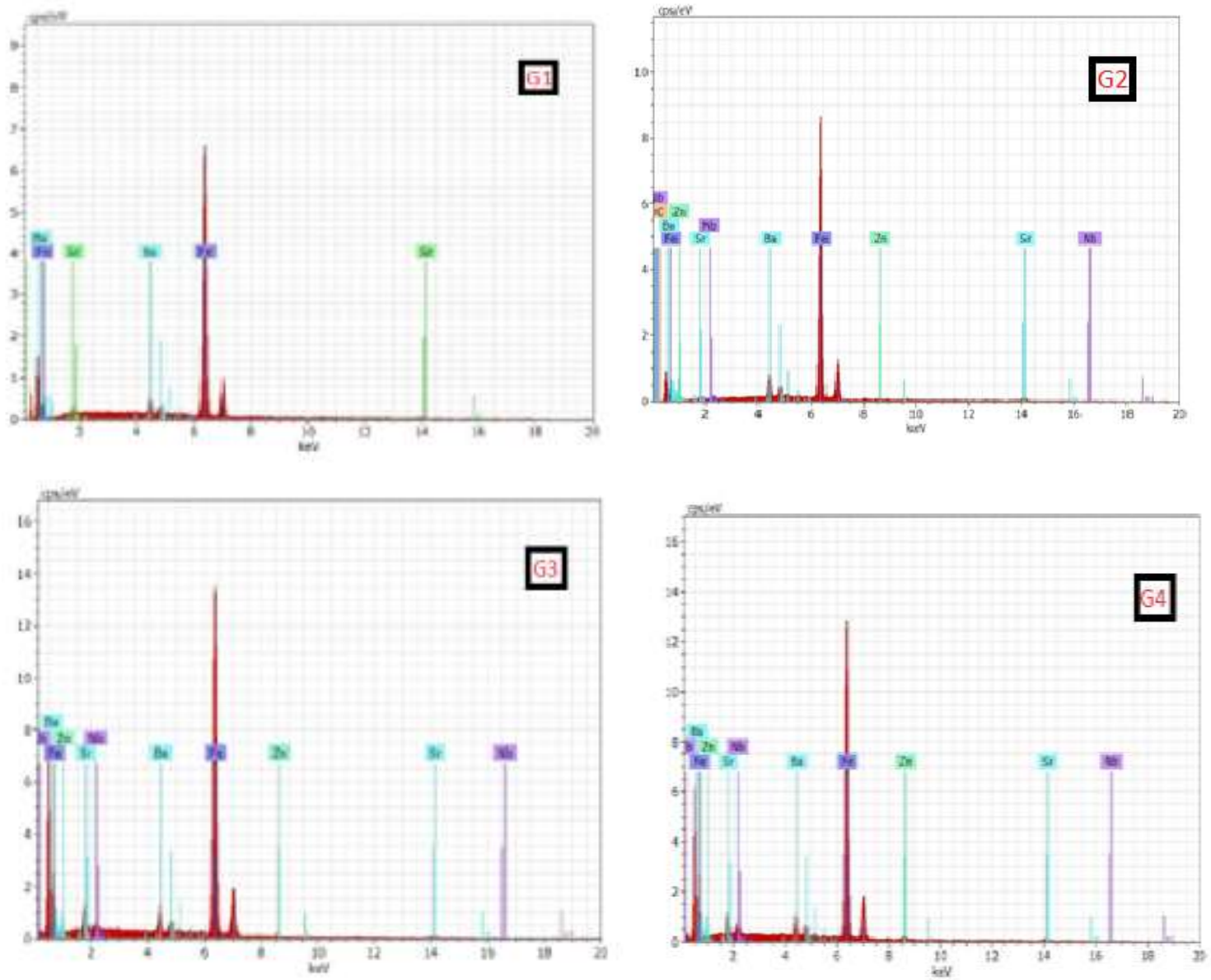


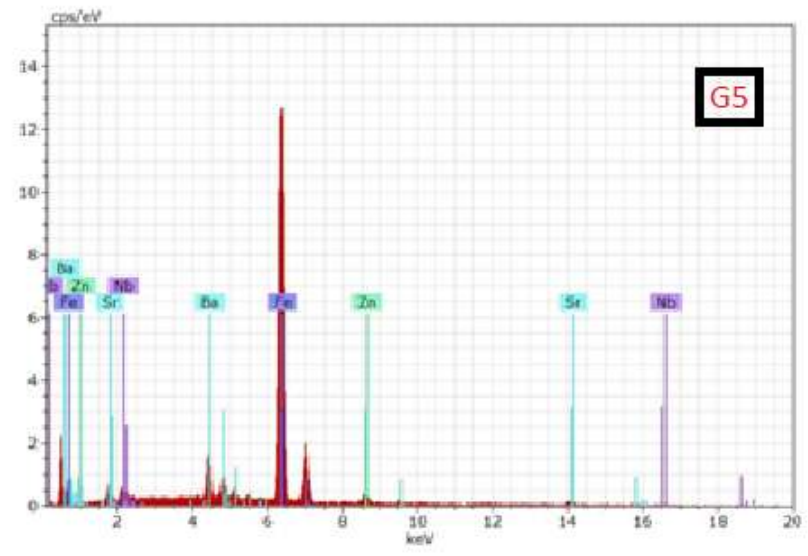

Fig.7:-EDAX spectrum of $\mathrm{Ba}_{0.5} \mathrm{Sr}_{0.5} \mathrm{Fe}_{12-2 \mathrm{x}} \mathrm{Nb}_{\mathrm{x}} \mathrm{Zn}_{\mathrm{x}} \mathrm{O}_{19}(\mathrm{X}=0,0.05,0.1,0.25,0.5 \mathrm{~mol} \%)$ of samples calcined at $950^{\circ} \mathrm{C}$

\section{Magnetic properties:-}

Fig.8 shows the measured hysteresis loops for representative $\mathrm{Ba}_{0.5} \mathrm{Sr}_{0.5} \mathrm{Fe}_{12-2 \mathrm{x}} \mathrm{Nb}_{\mathrm{x}} \mathrm{Zn}_{\mathrm{x}} \mathrm{O}_{19}$ samples as a function of applied magnetic field $\pm 15 \mathrm{KOe}$. The value of coercivity, saturation magnetization and remanence magnetization were observed from these loops. The estimated values of coercivity, saturation and remanence magnetization are shown in fig 9 . It is clear from the figure that the saturation magnetization $\left(M_{s}\right)$ increased from $74.7 \mathrm{emu} / \mathrm{g}$ at $\mathrm{X}=0$ to $75.2 \mathrm{emu} / \mathrm{g}$ at $\mathrm{X}=0.25$ and then slightly decreased at the value of $43.1 \mathrm{emu} / \mathrm{g}$ with the increase of doping content at $\mathrm{X}=0.5$. The remanence magnetization decreased slightly from $35.7 \mathrm{emu} / \mathrm{g}$ for the undoped sample at $\mathrm{X}=0$ down to the $14.7 \mathrm{emu} / \mathrm{g}$ for the doping level of $\mathrm{X}=0.5$. The decrease in magnetization by further increase in $\mathrm{Nb}-\mathrm{Zn}$ content could be related to the presence of $\alpha-\mathrm{Fe}_{2} \mathrm{O}_{3}$ for $\mathrm{X}=0.5$. The value of coercivity first increases from $1877 \mathrm{Oe}$ at $\mathrm{X}=0$ and reached the maximum value of $2348 \mathrm{Oe}$ at $\mathrm{X}=0.1$ and then drops drastically at $1164 \mathrm{Oe}$ at $\mathrm{x}=0.5$. The $\mathrm{Nb}-\mathrm{Zn}$ doped with $\mathrm{Ba}-\mathrm{Sr}$ hexaferrite with $\mathrm{X}$ up to 0.5 resulted in the reduction of coercivity and improved saturation and remanence magnetization at relatively high level suitable for high density magnetic recording applications.

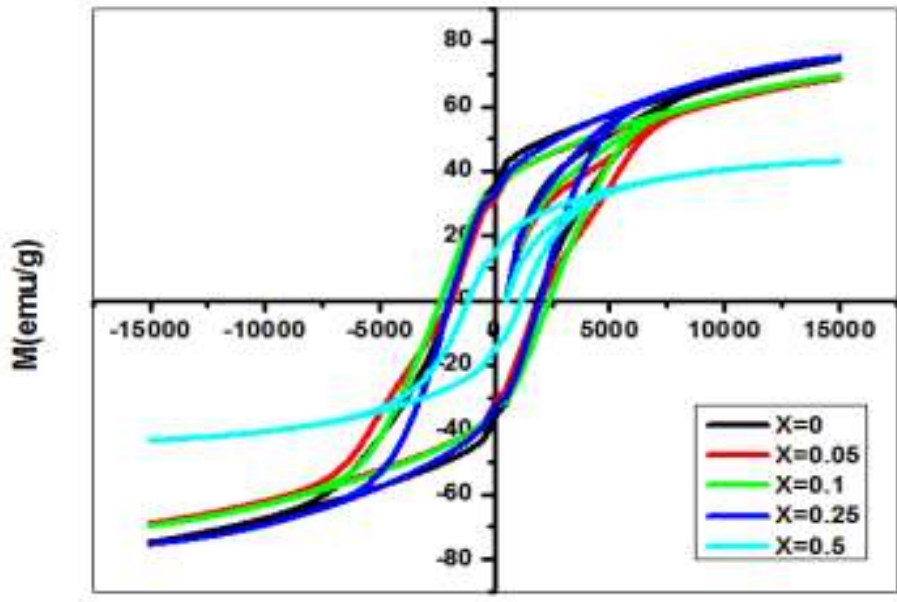

Applied fieid(Oe)

Fig.8:-Hysteresis loops of $\mathrm{Ba}_{0.5} \mathrm{Sr}_{0.5} \mathrm{Fe}_{12-2 \mathrm{x}} \mathrm{Nb}_{\mathrm{x}} \mathrm{Zn}_{\mathrm{x}} \mathrm{O}_{19}(\mathrm{X}=0,0.05,0.1,0.25,0.5 \mathrm{~mol} \%)$ at room temperature

The $\mathrm{Fe}^{3+}$ ions in M-type hexaferrite structure are distributed on five different crystallographic sites such as three octahedral $\left(2 \mathrm{a}, 12 \mathrm{k}\right.$ and $\left.4 \mathrm{f}_{2}\right)$, one tetrahedral $\left(4 \mathrm{f}_{1}\right)$ and one trigonal bipyramidal $(2 \mathrm{~b})$ sites. In the magnetically ordered state in $\mathrm{Ba}-\mathrm{Sr}$ hexaferrite, the $12 \mathrm{k}, 2 \mathrm{a}$ and $2 \mathrm{~b}$ sites have their spins aligned parallel to each other in the crystallographic c-axis, but $4 \mathrm{f}_{2}$ and $4 \mathrm{f}_{1}$ sites point in the opposite direction. This is likely due to the site occupancy of the doped metal ions in the different lattice site substitution of the $\mathrm{Fe}^{3+}$ ions in the spin up states appears to cause 
reduction in magnetization while the substitution in the spin down states may lead to an increase in the net magnetization. The material with high coercivity can be used to high density perpendicular magnetic recording [10].

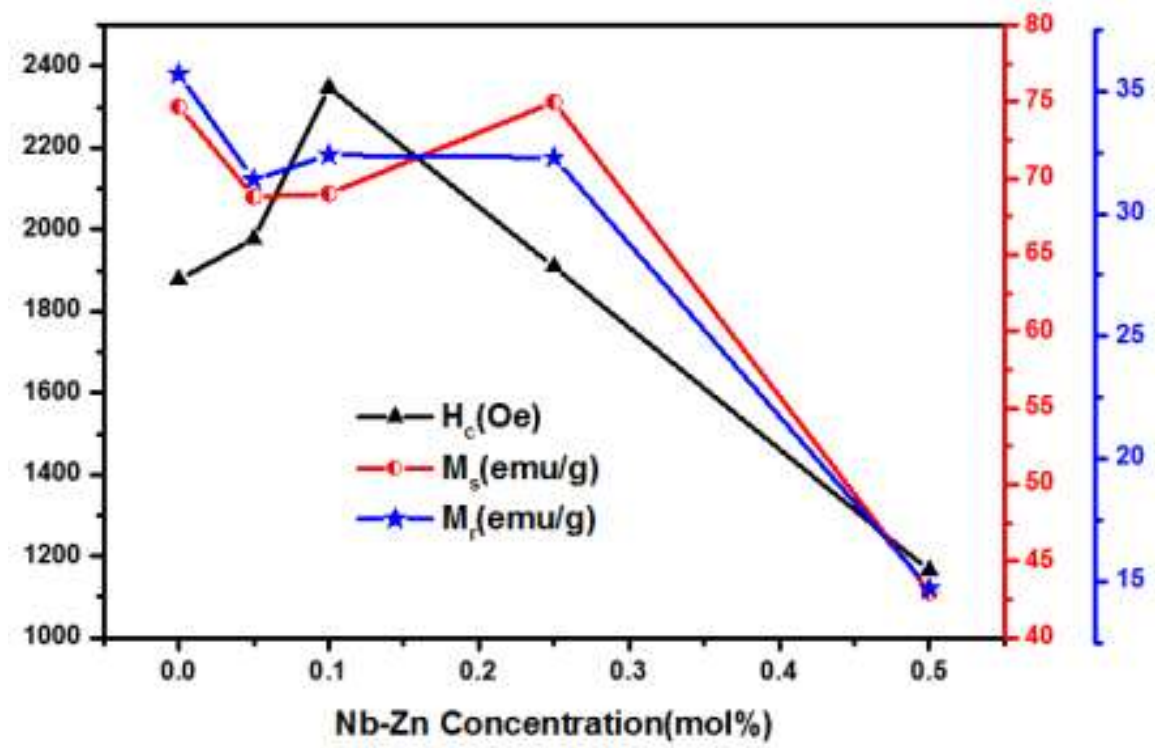

Fig.9:-The saturation magnetization $(\mathrm{Ms})$, the coercivity $(\mathrm{Hc})$ and remanance magnetization $\left(\mathrm{M}_{\mathrm{r}}\right)$ of samples $\mathrm{Ba}_{0.5} \mathrm{Sr}_{0.5} \mathrm{Fe}_{12-2 \mathrm{x}} \mathrm{Nb}_{\mathrm{x}} \mathrm{Zn}_{\mathrm{x}} \mathrm{O}_{19}(\mathrm{X}=0,0.05,0.1,0.25,0.5 \mathrm{~mol} \%$ at room temperature

\section{Conclusion:-}

M-type hexaferrite with compositions of $\mathrm{Ba}_{0.5} \mathrm{Sr}_{0.5} \mathrm{Fe}_{12-2 \mathrm{x}} \mathrm{Nb}_{\mathrm{x}} \mathrm{Zn}_{\mathrm{x}} \mathrm{O}_{19}(\mathrm{X}=0,0.05,0.1,0.25,0.5$ mol \%) were successfully synthesized by sol-gel method using D-glucose as fuel. TGA/DTA curve showed there is no weight loss above $850^{\circ} \mathrm{C}$ which confirming the formation of barium strontium hexaferrite. FTIR spectra showed the bands around 453 to $495 \mathrm{~cm}^{-1}$ which confirmed the presence of hexaferrite. XRD data of the synthesized samples confirmed the formation of hexagonal magnetoplumbite phase structures. The average crystallite size calculated from XRD is in the range of 39- $47 \mathrm{~nm}$. The values of lattice parameter were calculated using interplaner spacing formula. SEM micrographs showed the powder is well crystallized and the particles are hexagonal structure with the needle shape and platelet form. The platelet shaped hexaferrite can be used for microwave absorbing purpose. XRD results are in good agreement with the SEM results. The EDAX indicated the presence of ( $\mathrm{Ba}, \mathrm{Sr}, \mathrm{Fe}, \mathrm{Nb}$ and $\mathrm{Zn}$ ). The results show that the $\mathrm{Nb}-\mathrm{Zn}$ doped with $\mathrm{Ba}-\mathrm{Sr}$ hexaferrite with $\mathrm{X}$ up to 0.5 resulted in the reduction of coercivity and improved saturation magnetization and remanence magnetization at relatively high level suitable for high density perpendicular magnetic recording applications 


\section{Reference:-}

1. Yang Yujie, Wang Fanhou, Shao Juxiang, Huang Duohui and Cao Qilong 'Investigating the influence of Cr-Zn substitution on magnetic and structural properties of M-type $\mathrm{SrBaSm}$ hexaferrites $\mathrm{Sr}_{0.6} \mathrm{Ba}_{0.1} \mathrm{Sm}_{0.3} \mathrm{Fe}_{2}{ }_{20}$ ${ }_{x}\left(\mathrm{Cr}_{0.6} \mathrm{Zn}_{0.4}\right)_{\mathrm{x}} \mathrm{O}_{19}$ Chinese Journal of Physics,56, PP.67-74 (2018).

2. S. Kanagesan , S. Jesurani, R. Velmurugan, S. Prabu, T. Kalaivani 'Influence of $\mathrm{Zn}-\mathrm{Nb}$ on the Magnetic Properties of Barium Hexaferrite' Journal of superconductivity Novel Magnetism, 27 ,PP::811-815, (2014).

3. D S Winataputra, T L Ujiyanti and W A Adi 'The Structure, Magnetic and Absorption Properties of Zn-Ti Substituted Barium-Strontium Hexaferrite Prepared by Mechanochemical Process' Materials Science and Engineering 202, 012090, (2017).

4. Seyyed salman seyyed afahahi, Mojtaba Jafarian, Yomen Atassi 'Microstructural and magnetic studies on $\mathrm{BaMgxZn}_{\mathrm{x}} \mathrm{X}_{\mathrm{x}} \mathrm{Fe}_{12-4 \mathrm{x}} \mathrm{O}_{19}(\mathrm{x}=\mathrm{Zr}, \mathrm{Ce}, \mathrm{Sn})$ prepared via mechanical activation method to act as a microwave absorber in X-band' Journal of magnetism and magnetic materials,406,PP:184-191,2016.

5. Samikannu Kanagesan, Mansor Hashim, Sinnappan Jesurani, Thirunavukarasu Kalaivani, Ismayadi Ismail 'Microwave sintering of $\mathrm{Zn}-\mathrm{Nb}$ doped Barium Hexaferrite Synthesized via sol-gel method'Material science and applications,5,PP:171-176,(2014).

6. S. Kanagesan, S. Jesurani, R. Velmurugan and T.Kalaivani,Synthesis of Strontium Hexaferrite Using DFructose as a Fuel'Journal of transactions of the Indian Ceramic Society, 69(3),PP.199-202, (2010).

7. Safia Anjum, Sania Hameed, Saif Ullah Awan, Ejaz Amed, Abdul Sattar,Effect of Strontium doped M-Type Bariam Hexa-ferrites on Structural, Magnetic and Optical Properties, Optik - International Journal for Light and Electron Optics, PP.1-23,(2016).

8. Yujie Yang and Xian song Liu, Journal of Magnetism and Magnetic Materials, (2014).

9. S. Kanagesan, S. Jesurani, R. Velmurugan, S. Prabu, and T. Kalaivani, 'Magnetic properties of Ni-Co doped barium strontium hexaferrite' Journal of Material Science: Materials in Electronics, 23, PP: 1575-1579, (2012).

10. Sami.H.Mahmood and Ibrahim Bsoul, ' Tuning the Magnetic Properties of M-type Hexaferrites' Conductivity of Matter Material Science, PP:1-47, (2017). 